Sladan M. Svrzić, pukovnik, dipl. inž.

Dragan I. Cosović, potpukovnik, dipl. inž. VP 8115 Zemun

\section{VEROVATNOĆA OTKRIVANJA SIGNALA SA FREKVENCIJSKIM SKAKANJEM KORIŠĆENJEM SAVREMENIH IZVIĐAČKIH RADIO-PRIJEMNIKA}

UDC: $355.535 .2: 621.396 .62$

Rezime:

U članku su prezentirana najnovija naučna dostignuća u oblasti radio-izviđanja signala sa frekvencijskim skakanjem. Verovatnoca otkrivanja signala sa frekvencijskim skakanjem pomocu najsavremenijih izvidačkih radio-prijemnika ili digitalnih radio-goniometara, proračunava se na opstim osnovama, pri čemu se posebna pažnja posvecuje višekanalnim izviđačkim radio-prijemnicima, pretraživanju sa preklapanjem $i$ režimu frekvencijskog skakanja. U članku je detaljno opisano vremensko podešavanje koraka pretraživanja izviđačkog radio-prijemnika, sa korakom frekvencijskog skakanja izvidanog radio-signala. $\mathrm{Da}$ bi se problem pojednostavio, razmatrani su idealni uslovi.

Ključne reči: prošireni spektar, frekvencijsko skakanje, izviđački radio-prijemnik, pretraživanje, verovatnoca otkrivanja.

\title{
PROBABILITY OF INTERCEPTING FREQUENCY HOPING SIGNALS USING MODERN SEARCH RECEIVERS
}

\section{Summary:}

This article is intended to present the latest scientific findings about the interception of frequency hoping signals. The probability of intercepting frequency hopping signals by means of modern search receivers or scanning direction finders is calculated on a general basis and with particular attention to multichannel receivers and overlapping search and frequency hopping ranges. The article also deals in detail with the timing of the receiver sequence coinciding with the hopper sequence. For the sake of simplicity, ideal conditions are assumed.

Key words: spread spectrum, frequency hopping, search receiver, scanning, probability of interception.

\section{Uvod}

Ideja o korišcenju radio-signala sa ekspandovanim (proširenim) spektrom (Spread Spectrum Signals) javila se još u vreme Drugog svetskog rata, sa ciljem da se, prvenstveno u vojnim radio-komunikacionim i radio-lokacionim sistemima prenosa, obezbedi visok stepen imunosti na aktivno ometanje i nenamerne smetnje (feding, interferencija i drugo), i da se $u$ velikoj meri onemogući radio-izviđanje $i$ prisluškivanje prenošene informacije.

Bez obzira na to sto su laboratorijska ispitivanja pokazala da bi se, korišćenjem ovakvih sistema za radio-prenos signala u VF i VVF opsegu, snaga ometanog signala mogla drastično redukovati (za 
oko $25 \mathrm{~dB}$ ), i sto se radilo o analognim signalima, tadašnji tehnološki nivo nije dozvoljavao da se može organizovati i njihova masovna proizvodnja [1].

Ubrzani razvoj savremenih tehnologija primenjenih u telekomunikacijama, naročito za satelitske komunikacije i za vojne potrebe, doprineo je da sistemi za prenos signala sa ekspandovanim spektrom budu realizovani u većim serijama tek početkom osamdesetih godina, pošto je minijaturizacijom i gustinom pakovanja elektronskih komponenti tada rešen problem gabarita sistema, brzine rada, velike tačnosti takta, faze signala $i$ drugo.

Korišcenjem sistema za prenos signala sa ekspandovanim spektrom u radio-komunikacijama i radio-navigaciji, postižu se sledeće prednosti:

- u velikoj meri je onemogućeno ili otežano njihovo izviđanje i prisluškivanje, cime je postignuta tajnost prenosa;

- obezbeđen je visok stepen njihove zaštite od aktivnog ometanja, interferencije i višestruke propagacije;

- omogućeno je formiranje multipleksa u kojem svi kanali rade na istoj frekvenciji istovremeno;

- omogućena je realizacija selektivnog (adresnog) obraćanja učesnicima u sistemu;

- omogućeno je tačno određivanje rastojanja i lokacije stanice sa kojom se komunicira;

- omogućeno je kvalitetno komuniciranje preko medija u kojem je formirana polikanalna struktura [2].

Danas postoji veliki broj različitih konfiguracija digitalnih sistema sa ekspandovanim spektrom. Njihovo funkcionisanje se zasniva na zajedničkoj koncepciji da se korisni signal u digitalnom obliku u radio-predajniku sistema transformiše, takođe digitalnim postupkom, tako da se izvrši ekspanzija njegovog spektra u mnogo Širi frekvencijski opseg od onog koji je minimalno potreban za njegov prenos (spreading), obori mu se srednja spektralna gustina snage do nivoa šuma, pri čemu njegova ukupna snaga ostaje ista („efekat izlivanja vode iz bokala u Siroku tepsiju“). Na drugom kraju sistema, u radio-prijemniku, sprovodi se adekvatan digitalni postupak na dolazecem signalu sa ekspandovanim spektrom, tako da se izvrši skupljanje (despreading) njegovog spektra i podizanje spektralne gustine snage, ćime se korisni signal vraća u početni digitalni oblik.

Od velikog broja moguénosti za praktičnu realizaciju sistema zasnovanih na ovoj tehnici, najvažnije su:

- sistem sa direktnom sekvencom (Direct Sequence Spread Spectrum System - DS-SSS);

- sistem sa frekvencijskim skakanjem (Frequency Hopping Spread Spectrum System - FH-SSS);

- sistem sa vremenskim skakanjem (Time Hopping Spread Spectrum System - TH-SSS),

- hibridne metode [1].

Sistemi za prenos signala sa ekspandovanim spektrom, koji primenjuju tehniku frekvencijskog skakanja u podopsezima 5 do $10 \mathrm{MHz}$ siroko su primenjeni u vojsci, kao najprikladnija tehnika ekspandovanja spektra za takticke radio-veze u VVF opsegu od 30 do $90 \mathrm{MHz}$ [1, 2 i 11].

Njihove prednosti u odnosu na sisteme sa direktnom sekvencom i vremenskim skakanjem su:

- mogućnost korišćenja izuzetno šrokog opsega učestanosti, sa zabranom pojedinih sektora za skakanje (preskaču se); 
- ostvarivanje brzog ulaska u sinhronizaciju;

- slabo izražen problem „blizak-dalek“" učesnik (,near-far“);

- solidna imunost na aktivne ometačke signale i nenamerne smetnje (interferenciju);

- izražena tajnost prenosa (vrlo dobra imunost na prisluškivanje i izviđanje);

- mogućnost rada u kodnom multipleksu i mogućnost primene kodne sinhronizacije sa tri nivoa, koja je predviđena za rad u prisustvu izraženog fedinga;

- dobra mogućnost za prilagođenje antene i povećanje dometa manjom snagom radio-predajnika;

- jednostavno planiranje frekvencija i zaštitnih kodova i njihovo upisivanje;

- manje „zagadivanje“" spektra i manji međusobni uticaj u mrežama koje rade $u$ razlicitim podopsezima.

Suština tehnike frekvencijskog skakanja je u tome da noseća frekvencija u predajniku menja svoju lokaciju u okviru definisanog podopsega, $u$ diskretnim skokovima po pseudoslučajnom zakonu, tako da se korisni signal u nekom trenutku nalazi na jednoj frekvenciji punom snagom, a u sledećem momentu pojavljuje se na nekoj drugoj frekvenciji, takode punom snagom.

Mada koriste istu tehniku ekspandovanja spektra korisnog signala, ovi sistemi se razlikuju po nizu tehničkih osobina, a pre svega po brzini skakanja, $\mathrm{t} j$. broju skokova u sekundi. U tom smislu postoje sistemi sa sporim skakanjem do 20 skokova, sistemi sa srednjom brzinom skakanja od 20 do 500 skokova i sistemi sa brzim skakanjem sa 500 i više skokova/ s (do nekoliko hiljanja u sekundi). Takođe, razlikuju se i po tome da li skaču celo frekvencijsko područje ortogonalno ili u podopsezima širine 4, 5, 6 do $10 \mathrm{MHz}$ [2].
Zbog prednosti koje su navedene, za vojne taktičke radio-veze u VVF opsegu od 30 do $90 \mathrm{MHz}$ uglavnom se koriste sistemi sa srednjom brzinom frekvencijskog skakanja u podopsezima (RACALJAGUAR V, HARRIS-AN/PRC 117, ITT-SEL), a manje sistemi sa srednjom brzinom skakanja u celom području ortogonalno (ITT-SINCGARSV, COLLINSMP83, TADIRAN-VHF88) [2]. Svi ovi radio-uređaji uglavnom rade sa promenljivom snagom radio-predajnika do $50 \mathrm{~W}$, i primenjuju neku od vrsta digitalne modulacije ulaznog korisnog signala (obično CPSK modulaciju - Coherent Phase Shift Keying, zbog najmanje srednje verovatnoće greške ili nekoherentnu FSK - Frequency Shift Keying).

\section{Opis sistema sa frekvencijskim skakanjem}

U sistemima sa frekvencijskim skakanjem prenos informacija se zasniva na elementima standardnog sistema za digitalni prenos informacija sa nekoherentnom modulacijom FSK signala.

$\mathrm{Na}$ slici 1 prikazana je blok-šema opšte konfiguracije sistema, uz uvažavanje da se u praktičnim realizacijama, putem specijalno organizovane kontrole frekvencije, proces FSK modulacije realizuje takođe u samom sintetizatoru [1].

$\mathrm{U}$ radio-predajniku se signal binarne informacije iz izvora informacije moduliše u FSK modulatoru na cijem se izlazu pojavljuje signal $\mathrm{S}(\mathrm{t})$ koji ima dve diskretne vrednosti učestanosti, u zavisnosti od toga da li je u modulator pristigla „ 0 “ ili „1“ iz digitalne binarne povorke informacije.

Generator PSS generiše pseudoslucajni niz koji upravlja radom sintetizatora frekvencija, pa se na izlazu sintetizatora 

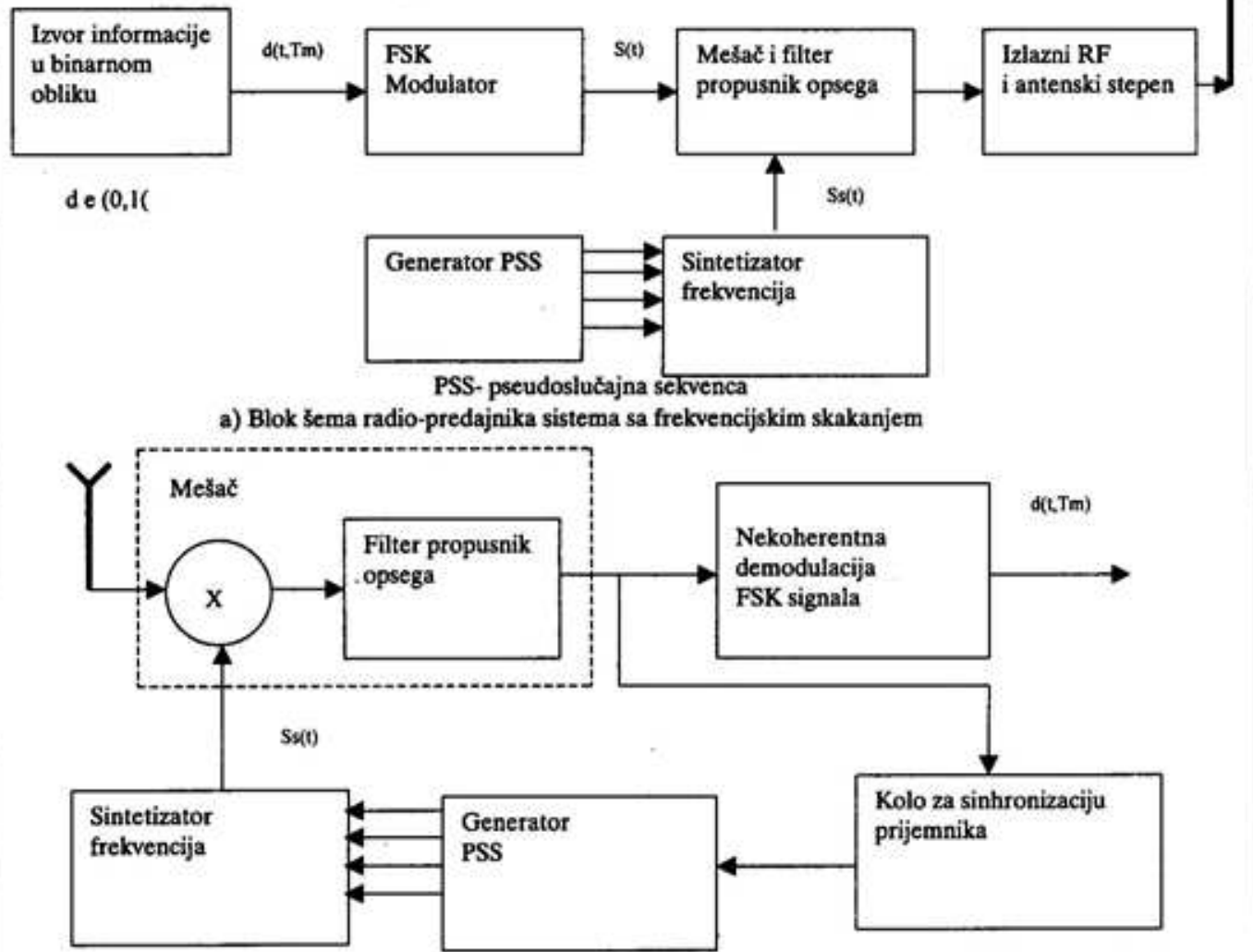

6) Blok Sema radio-prijemnika sistema sa frekvencijskim skakanjem

Sl. 1 - Blok-šema opšte konfiguracije sistema sa frekvencijskim skakanjem

generiše prostoperiodiěni signal $\mathrm{Ss}(\mathrm{t}) \check{c}_{\mathrm{ija}}$ se frekvencija skokovito menja po zakonu koji je određen pseudoslučajnom sekvencom. Pri tome frekvencija mora imati konačan i tačno definisan broj diskretnih vrednosti, i tačno određen period između dve sukcesivne promene.

Signali $\mathrm{S}(\mathrm{t})$ i $\mathrm{Ss}(\mathrm{t})$ jednovremeno dolaze u mešač u kojem se generiše izlazni signal čija se frekvencija menja u diskretnim vremenskim intervalima, pod jednovremenim uticajem binarnog signala koji nosi informaciju, i pseudoslučajne sekvence. Širina spektra ovog signala direktno zavisi od definisanog broja diskretnih vrednosti frekvencije $\mathrm{i}$ veličine razlike između dve sukcesivne vrednosti frekvencije i mnogostruko je veća od sirine spektra signala $S(t)$ na izlazu FSK modulatora. To znači da je procesom mešanja FSK signala koji nosi informaciju i izlaznog signala sintetizatora frekvencija izvršeno ekspandovanje spektra korisnog signala.

Na drugoj strani sistema, u radio-prijemniku, generiše se identična pseudosluCajna sekvenca koja je sinhronizovana sa pseudoslučajnom sekvencom u radio-predajniku, čime je obezbeđeno da se frekvencije signala sintetizatora u radio-pre- 
dajniku i radio-prijemniku sinhrono menjaju. To znači da signal na izlazu iz sintetizatora radio-prijemnika ima isti oblik Ss(t), kao i signal na izlazu sintetizatora radio-predajnika.

Nakon mesanja ulaznog signala sa sinhronim, lokalno generisanim signalom sintetizatora radio-prijemnika, na izlazu filtera propusnika opsega mešača dobija se signal cija je frekvencija jednaka razlici frekvencija ulaznih signala. Prema tome, opisanom operacijom na samom ulazu radio-prijemnika izvršena je kompresija spektra širokopojasnog signala u mnogo uži opseg koji ima korisni FSK signal. Pri tome je snaga korisnog signala na ulazu u FSK demodulator ista kao i u slučaju klasičnog digitalnog prenosa informacije, ali je prenos ostvaren sa mnogo manjom spektralnom gustinom signala.

Prikaz nosece frekvencije signala sa frekvencijskim skakanjem u vremenskom domenu dat je na slici 2. Upotrebljene oznake imaju sledeće značenje:

$\mathrm{T}_{\mathrm{h}}$ - vreme emisije radio-predajnika, $T_{p}$ - pauza između dve emisije za podešavanje sintetizatora,

$\mathrm{T}_{\mathrm{s}}$ - perioda skakanja.

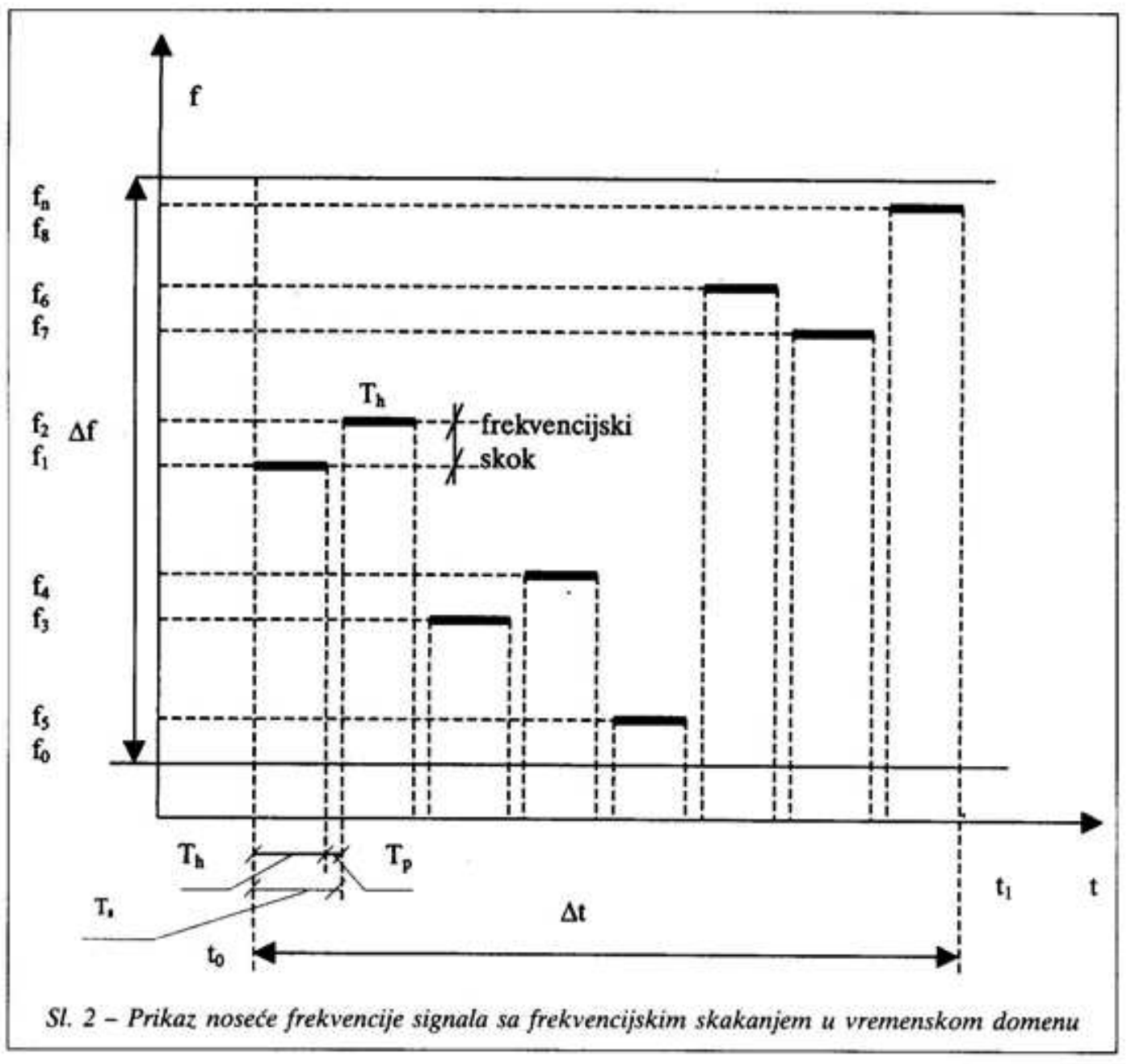


$\mathrm{U}$ toku emisije $T_{h}, T_{p}, T_{s}$ je konstantno.

$\Delta f=\left(f_{n}-f_{0}\right)$ dovoljno Sirok podopseg frekvencija radio-predajnika u cijim se granicama vrši skakanje frekvencije nosioca,

$\Delta t=\left(t_{1}-t_{0}\right)$ vremenski interval $u$ okviru kojeg se vrši posmatranje signala sa frekvencijskim skakanjem.

„BURST" (SKOK) - način predaje signala u etar kada emisija nije permanentna u vremenu, već se predajnik pobuđuje za emisiju samo diskretno, pri čemu je to vreme veoma kratko i ima svoj period ponavljanja. Signal je tada redovno komprimovan i obično nosi i zaglavlje (preambulu) u kojem se nalaze važni podaci (sinhroporuka, adresa i ostalo). To je i trenutna diskretna vrednost noseće frekvencije (jedan radio-kanal) zajedno sa korisnim signalom, koji traje samo za vreme jednog skoka $T_{h}$.

\section{Protivelektronska borba sa aspekta sistema koji primenjuju \\ frekvencijsko skakanje za \\ ekspandovanje spektra}

Sa stanovista vojne organizacije primena FH-SSS može se posmatrati sa dva aspekta:

- primena FH-SSS za Što pouzdaniji, tačniji i kvalitetniji radio-prenos korisnih informacija;

- mogućnosti primene elemenata PED na FH-SSS.

O mogućnostima primene elemenata PED na sisteme sa ekspandovanim spektrom koji koriste tehniku frekvencijskog skakanja, kod nas je veoma malo pisano, pa se u tom domenu uglavnom koristi retko dostupna inostrana literatura [6-10].
Kada je u pitanju PED (izviđanje, prisluškivanje i ometanje), osim ometanja akutni problem u vojnim komunikacijama je i problem elektronskog izviđanja (EI), pošto će efikasnost ometanja biti veća ukoliko se raspolaže sa više podataka o parametrima sistema koji se ometa (frekvencija, propusni opseg sistema, snaga predajnika, karakteristike antenskog sistema, vrsta upotrebljene modulacije, itd.). Postupak prikupljanja podataka (elektronsko izviđanje i goniometrisanje) stotinu je puta neefikasniji kada se primenjuje na sistemima sa frekvencijskim skakanjem srednjih brzina u odnosu na konvencionalne radio-sisteme prenosa [11]. To dobija na značaju ako se zna da je u okviru PED elektronsko izviđanje prvi i najvažniji postupak cije podatke eksploatišu elektronsko prisluškivanje i elektronsko ometanje.

Imajući u vidu navedene činjenice $\mathrm{i}$ osnovu datu u članku [6], u ovom radu ce se isključivo razmatrati sistem prenosa sa frekvencijskim skakanjem i to sa stanovišta EI $\mathrm{i}$ analize verovatnoće otkrivanja takvih signala upotrebom najsavremenijih izviđačkih radio-prijemnika i digitalnih savremenih radio-goniometara sa pretraživanjem.

\section{Radio-izviđačka oprema}

Još 1995. godine objavljen je članak [7] o tome kako se izviđački radio-prijemnici tipa ESMA (slika 3) mogu idealno iskoristiti kao celni uređaji za savremene VVF-UVF monitoring-sisteme, i da se mogu podešavati tako da veoma uspešno otkriju bilo koju frekvenciju u sirokom opsegu.

Kada se detektovani modulisani radio-signal prikazuje na odgovarajućem displeju u vremenskom domenu, predaj- 


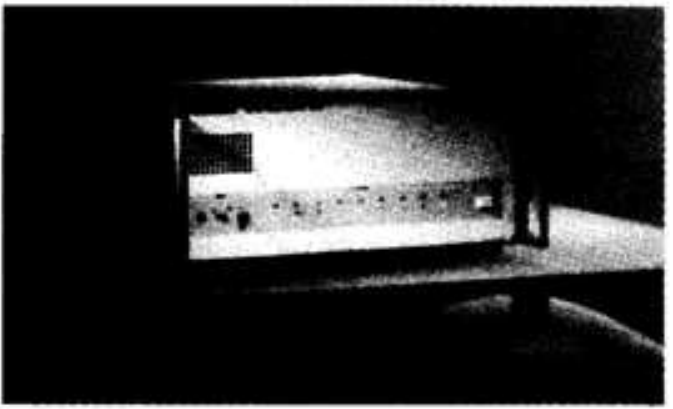

Sl. 3 - Izviđački radio-prijemnik ESMA za VHF-UHF opseg

nik kontinualne radio-emisije (CW) karakteriše se srednjom nosećom frekvencijom koja je konstantna u vremenu, dok se predajnik radio-signala sa frekvencijskim skakanjem karakteriše tipičnom sekvencom skakanja noseće frekvencije u određenom opsegu.

Povezivanje otkrivene frekvencije sa pravim izvorom zračenja (predajnikom) u uslovima gustog radio-saobraćaja, posebno kada se $\mathrm{u}$ istom frekvencijskom opsegu primaju signali od nekoliko radiopredajnika sa frekvencijskim skakanjem, prilično je otežano, jer se pojavljuje veliki broj različitih signala.

Nekoliko godina kasnije pokazano je da se ovaj komplikovani posao može jednostavnije rešiti korišćenjem digitalnog radio-goniometra sa pretraživanjem tipa DDFOxS (slika 4), koji u svom radio-prijemniku dodatno obrađuje ugao prijema svakog detektovanog signala (angle of arrival - AoA), uz pomoć radio-goniometarske antene i goniometarskog algoritma [8].

Ukoliko se izmereni prijemni ugao radio-signala (AoAs) prikaže kao funkcija frekvencije, predajnici sa frekvencijskim skakanjem mogu se na displeju monitora identifikovati pomoću karakterističnog izgleda noseće frekvencije u obliku „niske bisera“ koja je raspoređena linearno duž frekventne ose (slika 5).

Da bi se pomoću izviđačkog radioprijemnika ili radio-goniometra sa pretraživanjem detektovao signal radio-predajnika sa frekvencijskim skakanjem, potrebno je da se poklope sekvenca pretraživanja radio-prijemnika sa sekvencom skakanja radio-predajnika.

Sa zadatom slučajnom sekvencom skakanje noseće frekvencije radio-predajnika i nezavisnom sekvencom pretraživanja radio-prijemnika moguće je opisati samo verovatnoću otkrivanja signala sa frekvencijskim skakanjem.

U literaturi [9] opisan je slučaj kada se za izviđanje radio-signala sa frekvencijskim skakanjem koristi jednokanalni izviđački radio-prijemnik. Na uprošćeni način razmatrana je verovatnoća otkrivanja

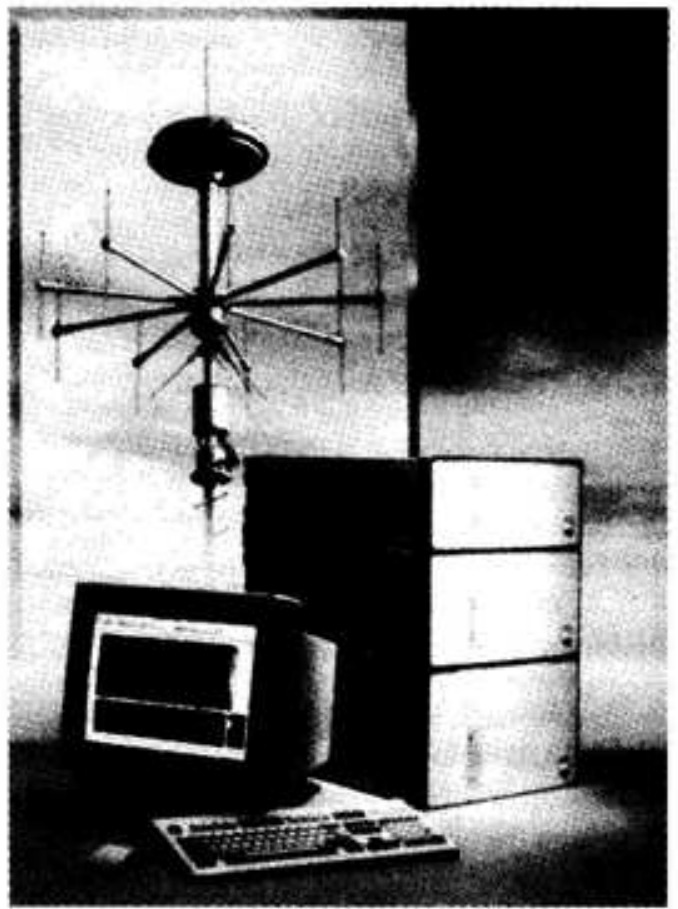

SL. 4 - Digitalni skenirajuci radio-goniometar DDFOxS za opseg od 0,5 do $1300 \mathrm{MHz}$ 


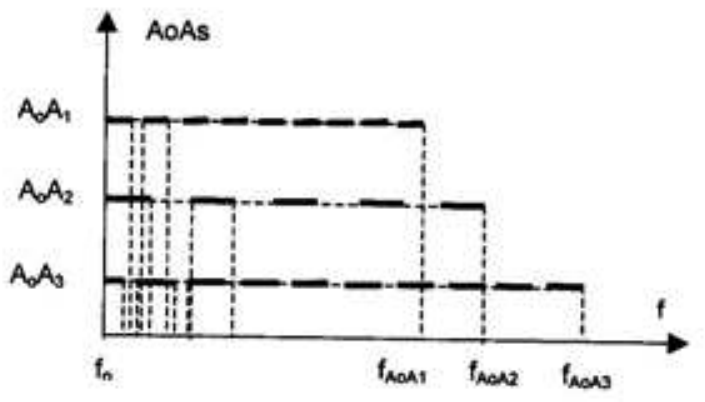

SI. 5 - Graficki prikaz zavisnosti ugla od nosece frekvencije tri razlicita radio-signala sa frekvencijskim skakanjem:

$f_{0}-f_{M N_{i}}-$ opseg $f_{4} u$ kojem frekvencijsko skakanje radio-predajnika dolazi sa uglom $\mathrm{A}_{0} \mathrm{~A}_{4}$

$f_{0}-f_{M_{2} A_{2}}$-opseg $f_{2} u$ kojem frekvencijsko skakanje radio-predajnika dolazi sa uglom $\mathrm{A}_{0} \mathrm{~A}_{2}$

$f_{0}-f_{\mu_{1}}-$ opseg $f_{3} u$ kojem frekvencijsko skakanje radio-predajnika dolazi sa uglom $A_{0} A_{3}\left(f_{1}=f_{2}=f_{3}\right)$

najmanje jednog skoka radio-predajnika, a ne razmatraju se detalji o vremenu zadržavanja izviđačkog radio-prijemnika na trenutnoj vrednosti noseće frekvencije. Nasuprot tome, u literaturi [10] opisuje se specijalni slučaj, kada se preklapa frekventni opseg skakanja i frekventni opseg pretraživanja, ali se ne razmatra vreme trajanja preklapanja sekvence radio-prijemnika i sekvence skakanja radio-predajnika.

\section{Pretpostavke za izračunavanje verovatnoće otkrivanja signala sa frekvencijskim skakanjem}

Pretpostavka je da je ponašanje radio-signala sa frekvencijskim skakanjem takvo da kanali u okviru opsega skakanja predstavljaju slučajni niz, a trenutni kanal se bira nezavisno od svih prethodnih i narednih kanala. Zbog toga će verovatnoća izbora za sve kanale iz opsega skakanja, ciji je ukupan broj $\mathbf{M}_{\mathrm{FH}}$, biti ista $\left(1 / \mathrm{M}_{\mathrm{FH}}\right)$, iako nije sigurno da ce se svaki kanal uvek pojaviti u okviru datog vremenskog perioda. Vreme zadržavanja ra- dio-predajnika sa frekvencijskim skakanjem na jednoj od više emitovanih vrednosti noseće frekvencije (vreme trajanja skoka) iznosi $T_{h}$. Ukoliko je vreme trajanja skoka radio-predajnika promenljivo, $T_{h}$ se predstavlja srednjom vrednošću. Radi pojednostavljenja računanja obično se uzima da graniéni kanali određuju frekvencijski opseg. Pri razmatranju frekvencijskog opsega koji zauzima signal sa frekvencijskim skakanjem zanemaruje se uticaj svih drugih signala.

$\mathrm{U}$ daljem razmatranju pretpostavlja se da izviđački radio-prijemnik, ili prijemnik radio-goniometra, neprekidno pretražuje zadati frekvencijski opseg sa korakom koji je isti kao korak skakanja emitovanog radio-signala. Centralne frekvencije pretraživanih kanala, kojih ukupno ima Msc, u zavisnosti od odabranog načina upravljanja pretraživanjem, mogu se pojaviti kao sekvenca bilo kog oblika, npr. kao linearna ili pseudoslučajna sekvenca. Međutim, jasno je da se svaki od izabranih kanala Msc pojavljuje samo jednom u okviru ciklusa pretraživanja. Podrazumeva se da se svaki put vrši kompletno pretraživanje zadatog frekvencijskog opsega. Vreme trajanja pretraživanja jednog ciklusa označava se sa

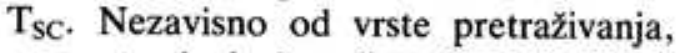
verovatnoća da će radio-prijemnik biti na određenom kanalu u nekom slučajno izabranom vremenu iznosi $1 / \mathrm{Msc}$ za svaki od Msc kanala. Za svaku specifičnu frekvenciju radio-prijemnika definisano je vreme zadržavanja $T_{d}$ (slika 6) koje sadrži vreme integracije $T_{i} i$ preostali period $T_{\text {Syn }} . T_{S y n}$ sadrži vreme koje je radio-prijemniku potrebno za podešavanje sintetizatora, kao i vreme neophodno za obradu signala (npr. radio-goniometru je potrebno vreme za izračunavanje ugla dolazećeg signala): 
$\mathrm{T}_{\mathrm{Syn}}=\mathrm{T}_{\mathrm{d}}-\mathrm{T}_{\mathrm{i}}$

Vreme integracije $T_{i}$ zavisi od vremena koje je potrebno za podešavanje filtera koji se koriste u prijemniku.

$\mathrm{Za}$ signale radio-predajnika cije je trajanje skoka $T_{h}$ manje od vremena integracije $\left(T_{b}<T_{i}\right)$, smatra se da nisu detektovani, odnosno da bi signal bio detektovan njegovo trajanje mora biti duže od vremena integracije $\left(T_{h}>T_{i}\right)$.

Izviđacki radio-prijemnik treba da bude „dovoljno moćan“ da bi bio u stanju da detektuje signal i kada je najmanje jedno vreme integracije u okviru intervala $\mathrm{T}_{\mathrm{h}}$ lažno, a kada su frekvencije radio-predajnika i radio-prijemnika jednake. To je veoma jednostavan pristup proceduri otkrivanja signala sa frekvencijskim skakanjem u izviđačkim radio-prijemnicima.

Pri razmatranju nisu uzeti u obzir međusobni odnosi između verovatnoće lažnog alarma, praga otkrivanja, nivoa $\mathrm{S} / \mathrm{N}$ (signal-sum), srednje vrednosti broja poklapanja i verovatnoće otkrivanja.

Frekvencijski opseg signala sa frekvencijskim skakanjem i zadati frekvencijski opseg radio-prijemnika trebalo bi bar delimično da se preklapaju po broju kanala $\mathrm{M}_{\mathrm{g}} \mathrm{u}$ zajedničkom osnovnom opsegu, pri čmu se mogu pojaviti različiti slučajevi (slika 7):

a) $\mathrm{M}_{\mathrm{g}}<\mathrm{M}_{\mathrm{SC}}$,

b) $\mathrm{M}_{\mathrm{g}}=\mathrm{M}_{\mathrm{SC}}<\mathrm{M}_{\mathrm{FH}}$,

c) $\mathrm{M}_{\mathrm{g}}=\mathrm{M}_{\mathrm{FH}}<\mathrm{M}_{\mathrm{SC}}$,

d) $\mathrm{M}_{\mathrm{g}}=\mathrm{M}_{\mathrm{SC}}=\mathrm{M}_{\mathrm{FH}}$.

Kod digitalne obrade signala mogu se primeniti višekanalni izviđački radioprijemnici koji koriste paralelno više identičnih filtera - detektora kanala. U slučaju da postoji više kanala za obradu se može koristiti npr. brza Furijeova transformacija. Kad god se radio-prijemnik postavi na specifičnu frekvenciju, istovremeno je aktivno $\mathrm{K}$ - filtera-detektora koji su podešeni na „K" različitih susednih kanala.

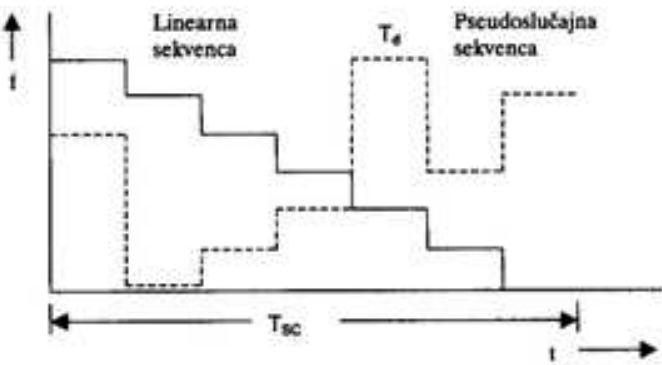

SI. 6-Prikaz sekvenci pretraživanja radio-prijemnika (linearna i pseudoslučajna)

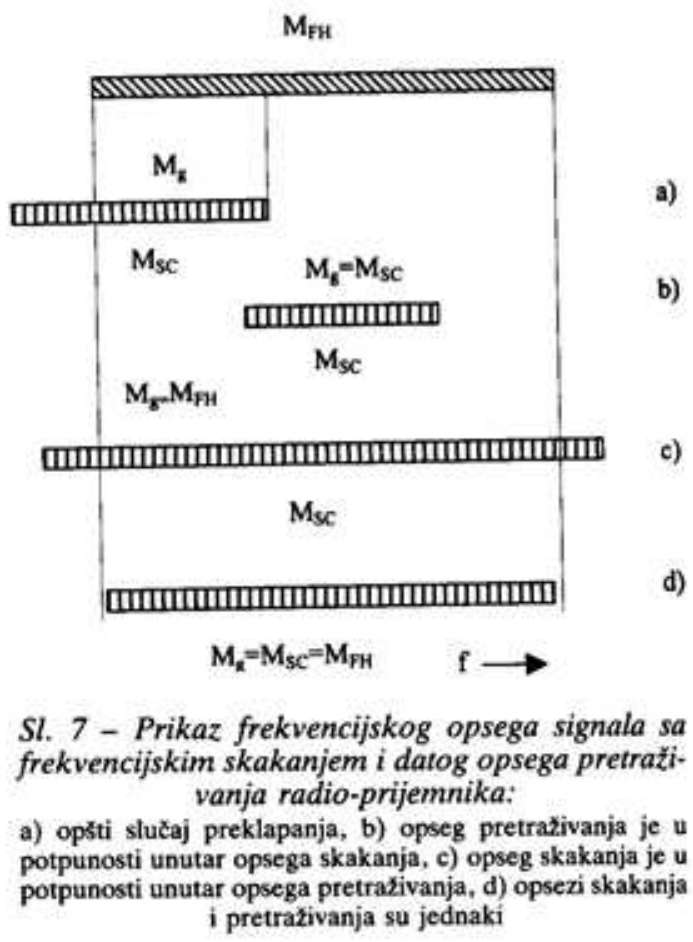

